\title{
Molecular and Clinical Profile of patients referred as Noonan or Noonan-like Syndrome in Greece: a cohort of 86 patients
}

\section{George Papadopoulos}

3rd Department of Pediatrics, National and Kapodistrian University of Athens, University General Hospital "ATTIKON", Greece

Anna Papadopoulou ( $\nabla$ anpapado@med.uoa.gr)

3rd Department of Pediatrics, National and Kapodistrian University of Athens, University General Hospital "ATTIKON", Greece

Konstantina Kosma

Department of Medical Genetics, National and Kapodistrian University of Athens,

\section{Anastasios Papadimitriou}

3rd Department of Pediatrics, National and Kapodistrian University of Athens, University General Hospital "ATTIKON", Greece

Vassiliki Papaevangelou

3rd Department of Pediatrics, National and Kapodistrian University of Athens, University General Hospital "ATTIKON", Greece

Christina Kanaka-Gantenbein

Division of Endocrinology, Diabetes and Metabolism, Center for Rare Paediatric Endocrine Diseases, First Department of

Paediatrics,National and Kapodistrian University of Athens, Agia Sophia" Children

Evangelia Bountouvi

3rd Department of Pediatrics, National and Kapodistrian University of Athens, University General Hospital "ATTIKON", Greece

Sophia Kitsiou-Tzeli

Medical School, National and Kapodistrian University of Athens

\section{Research Article}

Keywords: Noonan Syndrome, Rasopathies, PTPN11, Ras/MAPK pathway, Heart Defects, Craniofacial Dysmorphism

Posted Date: June 7th, 2022

DOI: https://doi.org/10.21203/rs.3.rs-1267516/v2

License: (c) (i) This work is licensed under a Creative Commons Attribution 4.0 International License. Read Full License 


\section{Abstract}

Noonan syndrome (NS) is an autosomal dominant disorder characterized by clinical and genetic heterogeneity. It belongs to a wider group of pathologies, Rasopathies, due to the implication of mutations in genes encoding components of the Ras/MAPK signalling pathway. Recording the genetic alterations across populations helps assessing specific features to specific genes which is essential for better disease's recognition, prognosis and monitoring. Herein, we report the clinical and molecular data of a Greek cohort comprising of 86 NS or NS-like patients admitted at a single tertiary Centre in Athens, Greece. The analysis was performed using Sanger and Next-Generation-Sequencing, comprising 14 different genes. The mutational rates of the confirmed NS-associated genes in the Greek NS population are: PTPN11 32.5\%; RIT1 5.8\%; SOS1 4.7\%; BRAF1.2\%; CBL 1.2\%; KRAS 1.2\%; MAP2K1 1.2\%; RAF1 1.2\%; SHOC21.2\%, corresponding to 50\% of positivity in total NS population. The genotype-phenotype analysis showed statistically significant differences regarding craniofacial dysmorphisms $(p=0.005)$ and pulmonary valve stenosis (PS) $(p<0.001)$ between patients harboring a mutation in any of the tested genes and mutation-free patients. Patients with at least one mutation had 6.71 times greater odds to develop PS compared to mutation-negative patients [OR=6.71, 95\%; $\mathrm{Cl}=(2.61,17.27)]$. PTPN11 positive patients showed higher frequency of epicanthal folds $(\mathrm{p}=0.004)$, ptosis $(p=0.001)$ and coarseness $(p=0.001)$ and lower frequency of neurological findings $(p=0.006)$, compared to patients with carrying mutations in other genes.

Conclusion: Craniofacial dysmorphismand PS prevail among mutation positive compared to mutation negative NS and NS-like patients while neurological defects are less common in PTPN11 mutated NS patients compared to patients with mutations in other genes The significant prevalence of the Ras/MAPK mutations (17.4\%), other than PTPN11, in Greek patients, highlights the necessity of a wider spectrum of molecular diagnosis.

\section{What Is Known}

- Noonan Syndrome (NS) has been associated with mutations in molecules-components of the Ras/MAPK pathway.

- Clinical and genetic description of NS patients worldwide helps establishing personalized monitoring.

\section{What Is New}

- NS and NS-like mutational rate in Greece reaches $50 \%$ with mutations identified mostly in PTPN11 (32.5\%), RIT1 (6\%) and SOS1 (4.7\%) genes.

The risk for pulmonary stenosis increases 6.71 -fold in NS mutation-positive patients compared to mutation-negative ones.

\section{Introduction}

Noonan syndrome (NS) (OMIM 163950) is an autosomal dominant disorder with marked variability either during one patient's lifetime. The estimated worldwide frequency ranges between $1 / 1,000-2,500$ births, although milder expression is thought to occur in 1/100 live births [1]. The syndrome has a multi-system involvement with key features including typical craniofacial dysmorphic characteristics and congenital heart defects, most commonly pulmonary valve stenosis (PS) [2]. Skin pigmentation, lymphatic abnormalities, cryptorchidism, ocular findings, skeletal defects, failure to thrive, developmental delay, and coagulation defects may also be present. Increased risk of developing haematological cancers and cases of rhabdomyosarcoma have also been reported $[2 ; 3]$.

NS development has been associated with dysregulation of the Ras/MAPK signalling pathway, one of the central molecular pathways regulating proliferation, differentiation and cell's survival [4]. Alterations resulting in instability of its moleculecomponents, favour their permanent activation, thus, leading to uncontrolled signalling downstream, affecting multiple organs and contribute to the development of cell proliferative disorders, such as cancer. Pathologies associated with germline mutations in genes encoding members of Ras/MAPK pathway present overlapping phenotypes and are grouped under the term of "Rasopathies"[5], with NS being the most common. 
Among the members of this molecular network, heterozygous mutations in the PTPN11 gene, account for the majority of all NS cases [6]. NS patients negative for PTPN11 mutations, may exhibit a pathogenic variant in a subset of genes encoding downstream regulators and effectors of Ras/MAPK pathway, while the role of other downstream genes such as $A 2 M L 1$ [7-9] is still under investigation $[10 ; 11]$. Variable mutational rates have been recorded, depending on the number of participants and on the method of patients' recruitment and evaluation [12; 13].

Extended use of Next Generation Sequencing (NGS) techniques during the last decade helps unfolding the heterogeneous genetic basis of NS. The discovery of new variants and new altered genes in NS/NS-like patients highlights potential therapeutic targets [14], and, in combination with specific features, contributes to establish accurate diagnosis and monitoring. Thus, germline mutations in HRAS have been associated with Costello syndrome [MIM 218040][15]; in BRAF, KRAS, MAP2K1, MAP2K2 with Cardiofacio-cutaneous(CFC) syndrome [MIM 115150][16] and in SPRED1 with Legius syndrome [MIM 611431] [17]. In clinical practice, however, it is often complicated to distinguish syndromes with overlapping phenotypes, especially in young age, as both severity and clinical heterogeneity make the diagnosis challenging.

Our group had previously published PTPN11 analysis by Sanger sequencing in 60 individuals clinically characterized as NS/NSlike Greek patients[18]. The current study expands the genetic analysis in 14 Rasopathy-associated genes using NGS and presents a more comprehensive molecular and clinical profile of this cohort with inclusion of 26 more patients, along with genotype-phenotype correlations. The genetic testing of the additional genes increases the mutational rate in the NS Greek population confirming the necessity of molecular diagnosis with accurate diagnostic tools.

\section{Materials And Methods}

\section{Patients}

Study's cohort consists of 86 Greek neonates, children and teenagers recruited during 2005-2018, with the clinical suspicion of NS or NLS. Among them, 48 patients had been previously found negative for PTPN11 mutations, and 16 had no molecular testing. The clinical and molecular characteristics of 22 PTPN11 patients (presented in our previous work [18] and recruited during the same period) were also presented and included in statistical analysis of the total Greek NS population. Patients with phenotypic similarities to NS were referred by pediatricians $(38 / 86,44 \%)$, cardiologists $(29 / 86,34 \%)$, endocrinologists $(12 / 86,14 \%)$, neurologists $(5 / 866 \%)$ and dermatologists $(2 / 86,2 \%)$ to our outpatient clinics and were further assessed by a clinical geneticist at the Department of Medical Genetics of Athens University Medical School for evidence of major or minor anomalies. All phenotypes were systematically evaluated and registered by clinical geneticists at the Department of Medical Genetics of the National and Kapodistrian University of Athens. In every patient referred all organic system's impairment, which are involved in NS have been checked as cardiological, endocrine, hematology, urinary,skeletal, skin, hearing, vision and dental. Dysmorphic features were thoroughly itemized and detailed family history as well as a karyotype was undertaken in each case. Patients that fulfilled the criteria developed by Van der Burgt et al [19] (Table 1) as well as individuals with a highly suggestive phenotype who lacked a definitive NS diagnosis were referred consecutively to the Research Lab of the $3^{\text {rd }}$ Department of Peadiatrics, of the National and Kapodistrian University Athens for molecular investigation. Major and minor criteria of NS are depicted in Table 1. In this scoring system patients are first classified according to the facial features (typical or suggestive); and if "typical", the diagnosis of NS is established in the presence of any other major sign (or two minor signs), while in cases with "suggestive" NS face there is need of two major (or three minor) criteria to confirm the NS diagnosis.

Table 1. Noonan syndrome minor and minor criteria-scoring system (van der Birgt et al., प) 


\begin{tabular}{|lll|}
\hline Findings & A major & B minor \\
\hline Facial & Typical face & Suggestive face \\
\hline Cardiac & Pulmonary valve stenosis and/or typical ECG & Other defect \\
\hline Height & $<3^{\text {rd }}$ centile & $<10^{\text {th }}$ centile \\
\hline $\begin{array}{l}\text { Chest } \\
\text { wall }\end{array}$ & Pectus carinatum/excavatum & Broad thorax \\
\hline $\begin{array}{l}\text { Family } \\
\text { history }\end{array}$ & First-degree-relative definite NS & First-degree-relative suggestive NS \\
\hline $\begin{array}{l}\text { Other } \\
\text { All three (males): mental retardation, cryptorchidism, } \\
\text { and lymphatic dysplasia }\end{array}$ & $\begin{array}{l}\text { One of three: mental retardation, cryptorchidism, and } \\
\text { lymphatic dysplasia }\end{array}$ \\
\hline
\end{tabular}

Definite NS: 1A plus one of 2A-6A or two 2B-6B; 1B plus two of 2A-6A or three of 2B-6B

\section{Molecular study}

Genomic DNA was isolated from peripheral blood lymphocytes (NucleoSpin Blood, Macherey-Nagel, Duren, Germany). All samples were tested for 14 RASopathy-associated genes using NGS except from the 22 patients previously found positive for PTPN11 mutations. Targeted analysis referred to PTPN11(NM_002834.5), SHOC2(NM_007373.4), RAF1(NM_002880.4), BRAF(NM_001374258.1), KRAS(NM_004985.5), NRAS(NM_002524.5), SOS1 (NM_005633.4), SPRED1(NM_152594.3), A2ML 1(NM_144670.6), MAP2K1(NM_002755.4), MAP2K2 (NM_030662.4), CBL(NM_005188.4), RIT1(NM_006912.6), and HRAS(NM_005343.4). NGS was performed using the lon S5 system (Thermo Fisher Scientific). Sequence reads were aligned to the reference sequence(GRCh38) lon reporter, followed by variant calling using Noonan workflow version 5.10. Sanger sequencing was used to confirm all clinically significant variants and fill in regions with insufficient coverage(horizontal $<100 \%$; vertical $<30 \%)$.

\section{Statistical Analysis}

Clinical and molecular description of NS Greek population, as well as statistical analyses was conducted for all 86 NS patients referred to our hospital. Initial statistical analysis was based on descriptive statistics. Categorical variables including mutations and polymorphisms were described by absolute and relative frequencies, while for continues variables mean, standard deviation, median, minimum, and maximum were provided. The association between clinical features and mutations/polymorphisms was assessed by Fisher's Exact test or Chi square test where the assumptions were met. Multiple comparisons adjustment was necessary due to the various clinical features to be tested across several mutations and polymorphisms. Each mutation/polymorphism was tested for association with 25 clinical features, thus statistical significance level was set to $a=0.05 / 25=0.002$ (Bonferroni correction). Statistically significant association between mutations and polymorphisms was not found. Entire statistical analysis was conducted in STATA 15.1 and all tests were two-sided

\section{Results}

\section{Molecular Study}

In the total Greek NS cohort, 50/86 cases (58\%) were positive for mutations in, at least, one of the Rasopathy-associated genes tested. Among them, 28 patients (32.5\%) were PTPN11 positive presenting 13 different PTPN11 mutations, with p.Tyr63Cys (6/28 cases; $22 \%)$; p.Asn308Asp(5/28 cases; $17 \%$ ) and p.Met504Val (4/28 cases; $14 \%$ ) being the most frequent. Among the PTPN11 negative patients (58/86), targeted sequencing of all 14 RASopathy-associated genes included in NGS panel revealed 22 more patients $(25.8 \%)$ with pathogenic or likely pathogenic variants. The most frequently altered reported genes were RIT1 (7 patients;5 different mutations), A2ML 1 (3 patients;3 different mutations), SOS1 (3 patients;3 different mutations) and SPRED1 (2 patients;2 different mutations). Two patients were compound heterozygotes; one (N022) carried a mutation both in 
PTPN11 and SPRED1 (p.Glu139Asp and p.Arg334Cys; respectively); and the second (N030) carried one mutation in A2ML 1 and another one in SOS1 (p.Arg657His and p.Met269Thr; respectively).

Mutations in $B R A F, C B L, K R A S, M A P 2 K 1, R A F 1$ and $S H O C 2$ were found in 6 different patients while no mutation was identified in MAP2K2, NRAS or HRAS. Table 1 resumes molecular and clinical data of each patient with pathogenic, likely pathogenic mutations or variants of unknown clinical significance(VUS) in all genes. All mutations were heterozygous missense changes, except for c.1096-4_1096-1 del in the CBL gene. One novel mutation was identified in RIT1 gene (c.235C>G; p.Gln79Glu) (N013), which has been recently reported in public databases (dbSNP138,ExAC and 1000 genomes), however, no clinical symptoms have been provided. According to PolyPhen analysis (PolyPhen-2 v2) this variant is predicted to be damaging (score 1.00). N002 carried the c.4076G>A (p.Arg1359His) in the A2ML 1 gene which is characterized as VUS or likely benign. The patient presented with craniofacial dysmorphisms, short stature and cryptorchidism. However, as $A 2 M L 1$ has not been confirmed as a NS causative gene we excluded $A 2 M L 1$ positive samples from further statistical analysis, as well as patients with a SPRED1 mutations which have been associated with Legius syndrome. We also excluded from statistical analysis the patient that was positive for a RIT1 mutation characterized as VUS and the patient with the novel RIT1 mutation. Thus, the mutational rates of the confirmed NS-associated genes in the Greek NS population is: PTPN11 32.5\%; RIT1 5.8\%; SOS1 4.7\%; BRAF1.2\%; CBL 1.2\%; KRAS 1.2\%; MAP2K1 1.2\%; RAF1 1.2\%; SHOC21.2\%, corresponding to 50\% of positivity in total NS population.

\section{Presenting symptoms and clinical features of patients}

Table 2 shows patients' clinical features. In the total population mean age at diagnosis was $4.4 \pm 4.74$ years ( 1 month to 19 years) and male patients prevailed to female (56 vs.30). In all patients, variable combinations of craniofacial abnormalities were recorded such as microcephaly, epicanthal folds, ptosis, low nasal bridge, hypertelorism, down slanting palpebral fissures, low set/posteriorly rotated ears, papillomas, coarseness, and webbed/thick neck. Craniofacial dysmorphisms (98.8\%) and short stature $(67.4 \%)$ were the most frequent characteristics of the patients, while PS was the most prevalent among congenital heart defects (47.7\%). Neurological and skeletal defects were observed in $39.5 \%$ and $46.5 \%$ of patients, respectively and cryptorchidism in $25 \%$. No patient presented with seizures, lymphatic dysplasia, bleeding diathesis, cancer or macrocephaly, while sensorineural hearing loss, lymphedema or kidney disorders were rarely reported. Seven patients had a positive family history. As shown in Table 3, most patients presented with typical face and heart defect (49\%).

Table 2: Demographics and clinical features of study population 


\begin{tabular}{|c|c|c|c|c|c|}
\hline $\begin{array}{l}\text { Patients' } \\
\text { characteristics }\end{array}$ & $\begin{array}{l}\text { Totaopulation } \\
(\mathrm{N}=86)\end{array}$ & $\begin{array}{l}\text { Mutation positive patients } \\
(\mathrm{N}=43)\end{array}$ & $\begin{array}{l}\text { Mutation } \\
\text { negative } \\
\text { patients } \\
(\mathrm{N}=43)\end{array}$ & $\begin{array}{l}\text { PTPN11 mutation } \\
\text { positive patients } \\
(\mathrm{N}=28)\end{array}$ & $\begin{array}{l}\text { Other mutation positive } \\
\text { patients }(\mathrm{N}=15)\end{array}$ \\
\hline $\begin{array}{l}\text { Age at } \\
\text { diagnosis; } \\
\text { years } \\
\text { (mean } \pm \text { SD) }\end{array}$ & $4.4 \pm 4.7$ & $4.61 \pm 5.0$ & $4.21 \pm 4.4$ & $5.34 \pm 5.7$ & $3.2 \pm 3.1$ \\
\hline \multirow{2}{*}{$\begin{array}{l}\text { Sex; N (male vs } \\
\text { female) }\end{array}$} & \multirow[t]{2}{*}{$56 / 30$} & $23 / 20$ & $33 / 10$ & \multirow[t]{2}{*}{$17 / 11$} & \multirow[t]{2}{*}{$6 / 9$} \\
\hline & & $p=0.024$ & & & \\
\hline $\begin{array}{l}\text { Craniofacial } \\
\text { dysmorphism; } \\
N(\%)\end{array}$ & 85 (98.8) & $43(100)$ & $42(97.7)$ & $28(100)$ & 15 (100) \\
\hline $\begin{array}{l}\text { Microcephaly; } \\
\text { N (\%) }\end{array}$ & $8(9.3)$ & $5(11.7)$ & $3(7.0)$ & $3(10.7)$ & $2(13.3)$ \\
\hline \multirow{2}{*}{$\begin{array}{l}\text { Epicanthal } \\
\text { folds; N (\%) }\end{array}$} & \multirow[t]{2}{*}{33 (38.4) } & $30(69.8)$ & $3(7.0)$ & 24 (85.7) & $6(40.0)$ \\
\hline & & $p<0.001$ & & $p=0.004$ & \\
\hline \multirow[t]{2}{*}{ Ptosis; N (\%) } & \multirow[t]{2}{*}{$30(34.8)$} & $29(67.4)$ & $1(2.3)$ & $24(85.7)$ & 5 (33.3) \\
\hline & & $p<0.001$ & & $p=0.001$ & \\
\hline \multirow{2}{*}{$\begin{array}{l}\text { Low nasal } \\
\text { bridge; N (\%) }\end{array}$} & \multirow[t]{2}{*}{34 (39.5) } & $31(72.1)$ & $3(7.0)$ & \multirow[t]{2}{*}{$23(82.1)$} & \multirow[t]{2}{*}{$8(53.3)$} \\
\hline & & $p<0.001$ & & & \\
\hline \multirow{2}{*}{$\begin{array}{l}\text { Hypertelorism; } \\
\mathrm{N}(\%)\end{array}$} & \multirow[t]{2}{*}{$36(41.9)$} & $31(72.1)$ & $5(11.6)$ & \multirow[t]{2}{*}{$21(75)$} & \multirow[t]{2}{*}{$10(66.7)$} \\
\hline & & $p<0.001$ & & & \\
\hline \multirow{2}{*}{$\begin{array}{l}\text { Down slanting } \\
\text { palpebral } \\
\text { fissures; N (\%) }\end{array}$} & \multirow[t]{2}{*}{$28(32.6)$} & $25(58.1)$ & $3(7.0)$ & $20(71.4)$ & $5(33.3)$ \\
\hline & & $p<0.001$ & & $p=0.024$ & \\
\hline \multirow{2}{*}{$\begin{array}{l}\text { Low } \\
\text { set/posteriorly } \\
\text { rotated ears; N } \\
\text { (\%) }\end{array}$} & \multirow[t]{2}{*}{$36(41.9)$} & $32(74.4)$ & $4(9.3)$ & \multirow[t]{2}{*}{$23(82.1)$} & \multirow[t]{2}{*}{$9(60.0)$} \\
\hline & & $p<0.001$ & & & \\
\hline $\begin{array}{l}\text { Papillomas; N } \\
(\%)\end{array}$ & $1(1.2)$ & $1(2.3)$ & 0 & $1(3.6)$ & 0 \\
\hline \multirow{2}{*}{$\begin{array}{l}\text { Coarseness; N } \\
(\%)\end{array}$} & \multirow[t]{2}{*}{$46(53.5)$} & $31(72.1)$ & 15 (34.9) & $25(89.3)$ & $6(37.5)$ \\
\hline & & $p=0.001$ & & $p=0.001$ & \\
\hline \multirow{2}{*}{$\begin{array}{l}\text { Webbed/thick } \\
\text { neck; N (\%) }\end{array}$} & \multirow[t]{2}{*}{$36(41.9)$} & $32(74.4)$ & $4(9.3)$ & \multirow[t]{2}{*}{$23(82.1)$} & \multirow[t]{2}{*}{$9(60.0)$} \\
\hline & & $p=0.001$ & & & \\
\hline \multirow{2}{*}{$\begin{array}{l}\text { Heart disease; } \\
N(\%)\end{array}$} & \multirow[t]{2}{*}{$62(72.1)$} & 36 (83.7) & $26(60.5)$ & \multirow[t]{2}{*}{$23(82.1)$} & 13 (86.7) \\
\hline & & $p=0.016$ & & & \\
\hline Pulmonary & $41(47.7)$ & $30(69.8)$ & $11(25.6)$ & $20(71.4)$ & $10(66.7)$ \\
\hline & & $p<0.001$ & & & \\
\hline Hypertrophic & $5(5.8)$ & $3(7.0)$ & $2(4.7)$ & 0 & $3(20.0)$ \\
\hline (\%) & & & & $p=0.037$ & \\
\hline $\begin{array}{l}\text { Other } \\
\text { cardiological }\end{array}$ & $17(19.8)$ & 9 (20.9) & 8 (18.6) & 5 (17.9) & $4(26.7)$ \\
\hline
\end{tabular}


problems; $\mathrm{N}$

$(\%)$

\begin{tabular}{|llcccc|}
$\begin{array}{l}\text { Skeletal } \\
\text { features; } \mathbf{N}(\%)\end{array}$ & $40(46.5)$ & $18(41.9)$ & $22(51.2)$ & $11(39.3)$ & $7(46.7)$ \\
\hline $\begin{array}{l}\text { Low height; N } \\
\text { (\%) }\end{array}$ & $58(67.4)$ & $31(72.1)$ & $27(62.8)$ & $19(67.9)$ & $12(80.0)$ \\
\hline $\begin{array}{l}\text { Skin } \\
\begin{array}{l}\text { manifestations; } \\
\mathbf{N}(\%)\end{array}\end{array}$ & $7(8.1)$ & $4(9.3)$ & $3(7.0)$ & $1(3.6)$ & $3(20.0)$ \\
\hline $\begin{array}{l}\text { Neurological } \\
\text { features; } \mathbf{N}(\%)\end{array}$ & $34(39.5)$ & $14(32.6)$ & $20(46.5)$ & $5(17.9)$ & $9(60.0)$ \\
\hline
\end{tabular}

Others

\begin{tabular}{|llllll|}
$\begin{array}{l}\text { Hearing loss; N } \\
(\%)\end{array}$ & $1(1.2)$ & $1(2.3)$ & 0 & $1(3.6)$ & 0 \\
\hline $\begin{array}{l}\text { Cryptorchidism; } \\
\text { N(\%) }\end{array}$ & $14(25)$ & $7(30.4)$ & $7(21.2)$ & $2(11.8)$ & $5(83.3)$ \\
\hline $\begin{array}{l}\text { Kidney } \\
\text { disorders; N (\%) }\end{array}$ & $4(4.7)$ & $2(4.7)$ & $2(4.7)$ & 0 & $2(13.3)$ \\
\hline $\begin{array}{l}\text { Lymphedema; } \\
\text { N }(\%)\end{array}$ & $4(4.7)$ & $3(4.7)$ & $1(2.3)$ & $3(10.7)$ & 0 \\
\hline $\begin{array}{l}\text { Family history; } \\
\text { N (\%) }\end{array}$ & $7(8.1)$ & $7(14)$ & 0 & $5(17.9)$ & $2(13.3)$ \\
\hline
\end{tabular}

The comparison between mutation-positive and-negative patients revealed a higher frequency of heart disease $(p=0.016)$ and especially for PS $(p<0.001)$ (only 3 patients had hypertrophic cardiomyopathy, HCM) in patients who had a mutation in any of the tested genes compared to mutation-free patients. Specifically, patients with at least one mutation had 6.71 times greater odds to develop PS compared to mutation-negative patients [OR=6.71, 95\%; $\mathrm{Cl}=(2.61,17.27)$ ]. Epicanthal folds, ptosis, low nasal bridge hypertelorism, down slanting palpebral fissures, low set rotated ears, coarseness and webbed neck were more frequently observed in mutation positive patients compared to negative ones ( $p<0.001$ for all features). Additionally, the phenotypical combination of typical face and heart disease $(1 \mathrm{~A}+2 \mathrm{~A}$, Table 3$)$ was found in $65 \%$ of mutation-positive patients and in $33 \%$ of mutation-negative patients. No other significant correlation was found with respect to presence of growth and skeletal anomalies.

Table 3: Patients' scores according van der Burgt criteria 


\begin{tabular}{|c|c|c|c|c|c|c|c|c|c|c|}
\hline \multirow[t]{2}{*}{ Scoring } & \multicolumn{2}{|c|}{$\begin{array}{l}\text { Total } \\
\text { population } \\
(\mathrm{N}=86)\end{array}$} & \multicolumn{2}{|c|}{$\begin{array}{l}\text { Mutation } \\
\text { positive patients } \\
(\mathrm{N}=43)\end{array}$} & \multicolumn{2}{|c|}{$\begin{array}{l}\text { Mutation } \\
\text { negative } \\
\text { patients } \\
(\mathrm{N}=43)\end{array}$} & \multicolumn{2}{|c|}{$\begin{array}{l}\text { PTPN11 mutation } \\
\text { positive patients } \\
(\mathrm{N}=28)\end{array}$} & \multicolumn{2}{|c|}{$\begin{array}{l}\text { Other mutation } \\
\text { positive patients } \\
(\mathrm{N}=15)\end{array}$} \\
\hline & $\mathrm{n}$ & $\%$ & $\mathrm{n}$ & $\%$ & $\mathrm{n}$ & $\%$ & $\mathrm{n}$ & $\%$ & $\mathrm{n}$ & $\%$ \\
\hline $1 A+2 A$ & 42 & 48.84 & 28 & 65.12 & 14 & 32.56 & 19 & 67.86 & 9 & 60.00 \\
\hline $1 A+3 A$ & 9 & 10.47 & 5 & 11.63 & 4 & 9.30 & 5 & 17.86 & 0 & 0.00 \\
\hline $1 A+4 A$ & 8 & 9.30 & 3 & 6.98 & 5 & 11.63 & 2 & 7.14 & 1 & 6.67 \\
\hline $1 A+2 B+3 B$ & 3 & 3.49 & 1 & 2.33 & 2 & 4.65 & 1 & 3.57 & 0 & 0.00 \\
\hline $1 A+2 B+6 B$ & 5 & 5.81 & 1 & 2.33 & 4 & 9.30 & 0 & 0.00 & 1 & 6.67 \\
\hline $1 A+3 B+5 B$ & 1 & 1.16 & 1 & 2.33 & 0 & 0.00 & 0 & 0.00 & 1 & 6.67 \\
\hline $1 A+3 B+6 B$ & 6 & 6.98 & 0 & 0.00 & 6 & 13.95 & 0 & 0.00 & 0 & 0.00 \\
\hline $1 B+2 A+3 A$ & 2 & 2.33 & 0 & 0.00 & 2 & 4.65 & 0 & 0.00 & 0 & 0.00 \\
\hline $1 B+2 A+4 A$ & 2 & 2.33 & 1 & 2.33 & 1 & 2.33 & 0 & 0.00 & 1 & 6.67 \\
\hline $1 B+2 B+3 B+4 B$ & 1 & 1.16 & 0 & 0.00 & 1 & 2.33 & 0 & 0.00 & 0 & 0.00 \\
\hline $1 B+2 B+3 B+6 B$ & 1 & 1.16 & 1 & 2.33 & 0 & 0.00 & 1 & 3.57 & 0 & 0.00 \\
\hline $1 B+3 A+4 A$ & 5 & 5.81 & 1 & 2.33 & 4 & 9.30 & 0 & 0.00 & 1 & 6.67 \\
\hline $1 B+3 A+6 A$ & 1 & 1.16 & 1 & 2.33 & 0 & 0.00 & 0 & 0.00 & 1 & 6.67 \\
\hline
\end{tabular}

Regarding genotype-phenotypes associations, we compared patients' phenotypes harboring a mutation in a specific gene with patients harboring a mutation in any other gene. We observed a higher frequency of epicanthal folds $(p=0.004)$; ptosis $(p=0.001)$; down slanting palpebral fissures $(p=0.024)$ and coarseness $(p=0.001)$ in PTPN11 mutation positive patients compared to mutation-positive patients in other genes. On the other hand, intellectual disability of variable degree was less frequent in PTPN11 mutation positive patients compared with mutation-positive patients in other genes. $(p=0.008)$. The detailed description of the phenotypical features and the genetic findings for all patients is presented in the Supplementary table (Table_S1). Due to the small size of mutation-subgroups, further statistical analysis was not allowed..

The record of single nucleotide polymorphisms (SNPs) showed 27 different exonic SNPs, with A2ML 1 accounting for most of them (Table 4). Their frequencies varied from $1.6 \%$ to $100 \%$ in the total population. Variant c.660C $>A$ in MAP2K2 gene was observed in patients without neurological features or downward eye slant $[\mathrm{OR}=0.083,95 \% \mathrm{Cl}=(0.02,0.34) ; \mathrm{OR}=0.11,95 \% \mathrm{Cl}=$ $(0.02,0.45)$, respectively] (data not shown). Thirty-three (33/36) mutation-negative patients $v s 17(17 / 50)$ mutation-positive patients carried this polymorphism. No other correlation was found between a specific SNP and any clinical feature or mutation. It should be noted that all polymorphisms were also detected in patients who did not fulfilled NS criteria.

Table 4: Single nucleotide polymorphisms identified in study population 


\begin{tabular}{|c|c|c|c|}
\hline Polymorphism & Frequency (\%) & Polymorphism & Frequency (\%) \\
\hline$N R A S \_c .360 G>A$ & 1.6 & SPRED1_c.291G>A & 95.3 \\
\hline RIT1_c.31G>C & 98.4 & SPRED1_c.1044T>C & 98.4 \\
\hline SHOC2_c.457C>T & 1.6 & MAP2K1_c.-2A>G & 1.6 \\
\hline$K R A S \_c .483 G>A$ & 96.9 & MAP2K1_c.255C>T & 1.6 \\
\hline KRAS_c.643T >C & 32.8 & MAP2K1_c.711G>A & 1.6 \\
\hline A2ML1_c.186C>T & 9.4 & MAP2K1_c.804C>G & 1.6 \\
\hline A2ML1_c.196C>T & 1.6 & MAP2K2_c.192C>T & 12.5 \\
\hline A2ML1_c.619G>C & 1.6 & MAP2K2_c.453C>T & 39.1 \\
\hline A2ML1_C.1101T>C & 1.6 & MAP2K2_c.660C >A & 78.1 \\
\hline A2ML1_C.1109T>C & 1.6 & MAP2K2_c.1211C>T & 1.6 \\
\hline$A 2 M L$ 1_c.1275A>G & 17.5 & MAP2K2_C.1212G>A & 3.1 \\
\hline A2ML1_c.2367G>A & 98.4 & MAP2K2_C.1222C>T & 3.1 \\
\hline A2ML1_c.2550C>A & 98.4 & MAP2K2_C.1227C>T & 25 \\
\hline A2ML1_c.2868C>T & 6.3 & SOS1_c.553A>G & 1.6 \\
\hline A2ML1_c.2909G >A & 40.6 & SOS1_c.570C>T & 1.6 \\
\hline A2ML1_c.3237G>A & 50 & SOS1_c.984C>T & 1.6 \\
\hline A2ML1_c.3364C>T & 57.8 & SOS1_c.1964C>T & 3.2 \\
\hline A2ML1_c.3569C>T & 15.6 & SOS1_c.2376A>G & 100 \\
\hline A2ML1_c.3676_3677del & 17.5 & RAF1_C.171T >C & 1.6 \\
\hline$A 2 M L$ 1_c.3686A>G & 98.4 & $B R A F_{-} \mathrm{c} .723 \mathrm{G}>\mathrm{A}$ & 1.6 \\
\hline$A 2 M L$ 1_c.3769A $>G$ & 92.2 & $B R A F_{-}$c. $1462 A>C$ & 1.6 \\
\hline A2ML1_c.3843T $>C$ & 8.1 & $B R A F_{-}$c. $1929 A>G$ & 46.9 \\
\hline \multirow[t]{2}{*}{ A2ML1_c.4020A>G } & 95.3 & $B R A F_{-} \mathrm{C} .2128-2 \mathrm{~A}>\mathrm{TA}$ & 1.6 \\
\hline & & BRAF_c.2128-4TG & 4.8 \\
\hline
\end{tabular}

\section{Discussion}

The phenotype of Noonan and Noonan-like syndromes are recognised, or suspected, at birth, by experienced paediatricians and cardiologists and, later in life, by other specialties, such as neurologists, endocrinologists or dermatologists. Due to the overlapping phenotypes with other entities and because of the subsequent changing craniofacial features during life, it is often difficult to obtain a definite diagnosis based only on clinical criteria. The genetic analysis may help in ending the diagnostic odyssey of the patient and, sometimes, guides medical decisions for monitoring and therapy. In the case of NS and NS-like patients, the recording of mutational detection rates in different cohorts worldwide shows a great variation, depending on the clinical inclusion criteria stringency, the number of participants and the genetic testing applied[2; 11]. According to the published results, PTPN11 mutations account for $\sim 50 \%$ of cases, whereas the analysis of other Ras/MAPK related genes increases the mutational rate up to $70-80 \%[11 ; 20-22]$.

In Greece, the genetic analysis depicted 52 heterozygous pathogenic/likely pathogenic variants in 11 out of 14 genes tested in 86 NS patients, with PTPN11, RIT1 and SOS1 presenting the higher frequency. The current knowledge allows the recognition of 
the genetic basis of more NS patients. The screening of more Ras/MAPK related genes increased the NS and NS-like mutational rate in Greece from 28\%, reported in our previous work [18] including only PTPN11, to $51.4 \%$ in the current paper. Taking into consideration that $A 2 M L 1$ gene has not been confirmed as a NS gene and that SPRED1 has been associated with Legius syndrome,the mutational rate of NS patients in Greece is formed as of $50 \%$. Phenotypically, our findings confirmed those observed in other cohorts with craniofacial dysmorphisms, and pulmonary stenosis (PS) being significantly associated with the presence of mutations in any of the tested genes[2; 20].

PTPN11 mutations were observed in $32.5 \%$ of our population. The risk for pulmonary stenosis increased 7.85 -fold in NS mutation-positive patients compared to mutation-negative ones while intellectual disability of variable degree was negatively associated with PTPN11 mutations compared to the presence of mutations in other genes. All mutations found were missense and favour the open configuration of the enzyme allowing its permanent catalytic function[6;23]. Among the more frequent variants, p.Asn308Asp has been also recorded as the most prevalent in other populations, reaching 20\% in Europe, USA, Argentina[21; 24], Brazil[25] and 11\% in South India[12].

It has been suggested that RIT1 mutated NS patients present higher rates of HCM compared to other NS patients[13;26]. Although RIT1 was the second most frequently altered gene in our cohort, detected in $6 \%$ of total NS population, we could not confirm the above clinical relevance because of the rarity of patients with HCM in our population. The detected mutational rate is similar to previous studies[13; $27 ; 28]$ worldwide $(4 \%-9 \%)$. All but one mutations detected have already been described in the literature and cluster at codons encoding highly conserved amino acids in functionally important domains. However, the most commonly observed mutations in other cohorts -at positions 57 and 82 of the protein-[13; 28; 29] were absent from our population. The most frequent variant was p.Ser35Thr (3/5 of RIT1 patients) which has been associated with activated MAPK signalling[13]. The identified novel variant p.GIn79Glu corresponds to an oncogenic RAS alteration p.GIn61Glu, implicated in the activation of MAPK signalling in a cell-specific manner[13]. These findings, together with pathogenicity prediction and clinical signs provide strong evidence for the causality of p.GIn79Glu mutation. Phenotypically, this patient (N0880) presented craniofacial dysmorphisms, webbed/thick neck, intellectual disability, cryptorchidism and short stature.

Four patients (4.7\%) of our cohort presented 4 different mutations in the SOS1 gene[2], the second-most-common genetic cause of NS worldwide, accounting for $~ 15 \%$ of NS cases[29-31]. All variants observed in our patients have been previously described[30; 32] and reside in regions that may disrupt the autoinhibited protein's conformation[30]. The associated phenotypes of our patients were clearly in NS spectrum, without the specific features attributed to SOS1 mutations such as ectodermal features and macrocephaly[30].

Among the other genes tested, mutations were observed in BRAF, CBL, KRAS, MAP2K1(MEK1), RAF1 and SHOC2 at a lower frequency (1.2\%). Germline mutations in KRAS and BRAF genes have been associated with NS and CFC with a variable clinical phenotype depending on the affected residue, while somatic mutations are closely related to myeloid malignancies (KRAS), melanoma (BRAF) and other cancers[33-35]. Our patients with heterozygous either KRAS or BRAF mutations showed typical NS features. KRAS p.Asp153Val variant has already been published as de novo alteration associated with NS and CFC [33; 35; 36] and it is characterized as pathogenic. On the other hand, it has been shown that the observed BRAF mutation p.Glu501Gly, does not enhance ELK-dependent transcription similar to other mutations identified in the kinase domain of the protein[35]. RAF1, SHOC2 and $C B L$ are downstream effectors of the Ras/MAPK pathway which have been associated with specific clinical features in NS patients; RAF1 has been suggested to cause cardiomyopathy[37], SHOC2 a rare subset of NS with a unique phenotypic feature of loose anagen hair[38; 39] and $C B L$ has been linked to an entity that resembles NS and predispose to juvenile myelomonocytic leukaemia that may follow a variable course[40; 41]. Although pathogenicity has been attributed to all variants observed in our study, these patients presented craniofacial defects, PS but no other specific features.

According to our results, small-scale recording of NS genetic variants may deviate the genotype-phenotype associations that have been proposed for the NS or NLS associated genes, such as the presence of HCM in RIT1 carriers, or macrocephaly and ectodermal manifestations attributed to SOS1 mutation positive patients. What complicated more the definite diagnosis and the extraction of solid associations was the detection of genetic variants classified as of VUS in patients fulfilling the van der Burgt criteria. For instance, a patient with craniofacial dysmorphisms, carrier of the RIT1 p.Lys23Arg mutation (VUS) and a patient

Page $10 / 15$ 
with typical NS facial characteristics and heart defects but without skin manifestations revealed the SPRED1 p.Thr196Ile mutation (VUS). In line with this, four of our patients with a rather mild phenotype and typical NS face, revealed 4 different rare and non-synonymous variants in $A 2 M L 1$ gene classified as of VUS. Functional studies and detailed clinical information on A2ML 1 mutated NS patients reported in previous studies have put up the question of the driver role of $A 2 M L 1$ in RASopathies[8] as de novo variants have been identified in patients that hardly met the diagnostic criteria[7; 42]. Furthermore, results from in vitro analysis have failed to show an impact of $A 2 M L 1$ variants on RAS/MAPK activation[7; 42].

For the significant patients' number with unknown genetic cause or VUS in our cohort paediatricians should inform the patients for a long follow up and future reanalysis for mutations in other genes, recently associated with NS, like LTRZ1, or even genes from other molecular pathways that may collaborate with the Ras/MAPK pathway, such as mTOR[43]. Moreover, in some cases, functional studies have shown that the mutation detected does not stimulate the Ras/MAPK pathway, although the respective patient fulfills the diagnostic criteria. It would be possible that other genes or polymorphisms may have an additive or modifying effect on the phenotype, as the c.660C $>A$ in MAP2K2 which was observed in our patients without neurological features. Thus, frequent follow-up of patients with typical clinical NS diagnosis is essential for their appropriate and successful management. For patients with NS phenotype, the presence of a genetic variant in one of the Noonan genes, facilitates the padiatrician's planning for precise and multidisciplinary clinical guidance and also allows the referral for proper genetic counseling for the family.

It is certain that unravelling NS molecular basis, may help discovering new therapeutic targets and personalizing RASopathy monitoring. In particular, drugs that inhibit components of the Ras/MAPK pathway could be useful for treating RASopathy patients. In vivo experiments have shown that MEK inhibitor treatment during the early life stages may reduce or reverse NS defects in Raf1 or Sos1 mutant mice[44; 45]. In humans, it has recently been reported that trametinib, a highly selective reversible allosteric inhibitor of MEK1/2 activity might limit myocardial hypertrophy[14; 46] in NS patients with RIT1 mutations, while a complete remodelling of the entire central lymphatic system in a girl with NS and a SOS1 mutation has recently been reported[47].

\section{Abbreviations}

Cardiofacio- cutaneous syndrome (CFC), Hypertrophic Cardiomyopathy (HCM), Noonan syndrome (NS), Pulmonary valve stenosis (PS), Next Generation Sequencing (NGS), Single Nucleotide Polymorphisms (SNPs), Variants of Unknown clinical Significance (VUS)

\section{Declarations}

\section{Acknowledgments}

We cordially thank the families for their cooperation.

\section{Funding}

No financial assistance was received in support of the study

\section{Conflict of Interests}

The authors have no relevant financial or non-financial interests to disclose.

\section{Data availability}

Raw data are available upon request.

\section{Code of availability}

Not applicable 
Authors' contributions: G.P., A.Papadopoulou. and E.B. conducted material preparation, and wrote of the manuscript. Patient's stratification was performed by S.K-Tz., K.K., A.Papadimitriou., C. K-G. and V.P.. A.P. wrote the first draft of the manuscript and all authors commented on previous versions of the manuscript. All authors read and approved the final manuscript.

\section{Compliance with ethical standards}

\section{Ethical Approval}

This study was performed in line with the principles of the Declaration of Helsinki and its later amendments. Medical ethical approval was granted by the local medical ethics committee of Attikon University general hospital with the file number (4492/16.07.2019).

\section{Consent to participate}

Written informed consent was obtained from the participants or/and the parents of the participating children, as well as patients' assess where applicable.

\section{Consent to publish}

Not applicable.

\section{References}

1. Gross AM, Frone M, Gripp KW, Gelb BD, Schoyer L, Schill L, Stronach B, Biesecker LG, Esposito D, Hernandez ER, Legius E, Loh ML, Martin S, Morrison DK, Rauen KA, Wolters PL, Zand D, McCormick F, Savage SA, Stewart DR, Widemann BC, Yohe ME (2020) Advancing RAS/RASopathy therapies: An NCl-sponsored intramural and extramural collaboration for the study of RASopathies. Am J Med Genet A 182:866-876

2. Roberts AE, Allanson JE, Tartaglia M, Gelb BD (2013) Noonan syndrome. Lancet 381:333-342

3. Moschovi M, Touliatou V, Papadopoulou A, Mayakou MA, Nikolaidou-Karpathiou P, Kitsiou-Tzeli S (2007) Rhabdomyosarcoma in a patient with Noonan syndrome phenotype and review of the literature. J Pediatr Hematol Oncol 29:341-344

4. Yoon S, Seger R (2006) The extracellular signal-regulated kinase: multiple substrates regulate diverse cellular functions. Growth Factors 24:21-44

5. Rauen KA (2013) The RASopathies. Annu Rev Genomics Hum Genet 14:355-369

6. Tartaglia M, Mehler EL, Goldberg R, Zampino G, Brunner HG, Kremer H, van der Burgt I, Crosby AH, lon A, Jeffery S, Kalidas K, Patton MA, Kucherlapati RS, Gelb BD (2001) Mutations in PTPN11, encoding the protein tyrosine phosphatase SHP-2, cause Noonan syndrome. Nat Genet 29:465-468

7. Vissers LE, Bonetti M, Paardekooper Overman J, Nillesen WM, Frints SG, de Ligt J, Zampino G, Justino A, Machado JC, Schepens M, Brunner HG, Veltman JA, Scheffer H, Gros P, Costa JL, Tartaglia M, van der Burgt I, Yntema HG, den Hertog J (2015) Heterozygous germline mutations in A2ML1 are associated with a disorder clinically related to Noonan syndrome. Eur J Hum Genet 23:317-324

8. Brinkmann J, Lissewski C, Pinna V, Vial Y, Pantaleoni F, Lepri F, Daniele P, Burnyte B, Cuturilo G, Fauth C, Gezdirici A, Kotzot D, Gulec EY, lotova V, Schanze D, Ramond F, Havlovicova M, Utine GE, Simsek-Kiper PO, Stoyanova M, Verloes A, De Luca A, Tartaglia M, Cave H, Zenker M (2021) The clinical significance of A2ML1 variants in Noonan syndrome has to be reconsidered. Eur J Hum Genet 29:524-527

9. Grant AR, Cushman BJ, Cave H, Dillon MW, Gelb BD, Gripp KW, Lee JA, Mason-Suares H, Rauen KA, Tartaglia M, Vincent LM, Zenker M (2018) Assessing the gene-disease association of 19 genes with the RASopathies using the ClinGen gene curation framework. Hum Mutat 39:1485-1493 
10. Yamamoto GL, Aguena M, Gos M, Hung C, Pilch J, Fahiminiya S, Abramowicz A, Cristian I, Buscarilli M, Naslavsky MS, Malaquias AC, Zatz M, Bodamer O, Majewski J, Jorge AA, Pereira AC, Kim CA, Passos-Bueno MR, Bertola DR (2015) Rare variants in SOS2 and LZTR1 are associated with Noonan syndrome. J Med Genet 52:413-421

11. Tafazoli A, Eshraghi P, Pantaleoni F, Vakili R, Moghaddassian M, Ghahraman M, Muto V, Paolacci S, Golyan FF, Abbaszadegan MR (2018) Novel mutations and their genotype-phenotype correlations in patients with Noonan syndrome, using next-generation sequencing. Adv Med Sci 63:87-93

12. Athota JP, Bhat M, Nampoothiri S, Gowrishankar K, Narayanachar SG, Puttamallesh V, Farooque MO, Shetty S (2020) Molecular and clinical studies in 107 Noonan syndrome affected individuals with PTPN11 mutations. BMC Med Genet $21: 50$

13. Aoki Y, Niihori T, Banjo T, Okamoto N, Mizuno S, Kurosawa K, Ogata T, Takada F, Yano M, Ando T, Hoshika T, Barnett C, Ohashi H, Kawame H, Hasegawa T, Okutani T, Nagashima T, Hasegawa S, Funayama R, Nakayama K, Inoue S, Watanabe Y, Ogura T, Matsubara Y (2013) Gain-of-function mutations in RIT1 cause Noonan syndrome, a RAS/MAPK pathway syndrome. Am J Hum Genet 93:173-180

14. Nelson R (2019) Mek Inhibitor Reverses Hypertrophic Cardiomyopathy in RIT1 Mutated Noonan Syndrome: For the first time, hypertrophic cardiomyopathy was reversed in Noonan syndrome associated with a RIT1 mutation. Am J Med Genet A 179:1408-1409

15. Aoki Y, Niihori T, Kawame H, Kurosawa K, Ohashi H, Tanaka Y, Filocamo M, Kato K, Suzuki Y, Kure S, Matsubara Y (2005) Germline mutations in HRAS proto-oncogene cause Costello syndrome. Nat Genet 37:1038-1040

16. Rodriguez-Viciana P, Tetsu O, Tidyman WE, Estep AL, Conger BA, Cruz MS, McCormick F, Rauen KA (2006) Germline mutations in genes within the MAPK pathway cause cardio-facio-cutaneous syndrome. Science 311:1287-1290

17. Brems H, Chmara M, Sahbatou M, Denayer E, Taniguchi K, Kato R, Somers R, Messiaen L, De Schepper S, Fryns JP, Cools J, Marynen P, Thomas G, Yoshimura A, Legius E (2007) Germline loss-of-function mutations in SPRED1 cause a neurofibromatosis 1-like phenotype. Nat Genet 39:1120-1126

18. Papadopoulou A, Issakidis M, Gole E, Kosma K, Fryssira H, Fretzayas A, Nicolaidou P, Kitsiou-Tzeli S (2012) Phenotypic spectrum of 80 Greek patients referred as Noonan syndrome and PTPN11 mutation analysis: the value of initial clinical assessment. Eur J Pediatr 171:51-58

19. van der Burgt I (2007) Noonan syndrome. Orphanet J Rare Dis 2:4

20. Chen PC, Yin J, Yu HW, Yuan T, Fernandez M, Yung CK, Trinh QM, Peltekova VD, Reid JG, Tworog-Dube E, Morgan MB, Muzny DM, Stein L, McPherson JD, Roberts AE, Gibbs RA, Neel BG, Kucherlapati R (2014) Next-generation sequencing identifies rare variants associated with Noonan syndrome. Proc Natl Acad Sci U S A 111:11473-11478

21. Tartaglia M, Martinelli S, Stella L, Bocchinfuso G, Flex E, Cordeddu V, Zampino G, Burgt I, Palleschi A, Petrucci TC, Sorcini M, Schoch C, Foa R, Emanuel PD, Gelb BD (2006) Diversity and functional consequences of germline and somatic PTPN11 mutations in human disease. Am J Hum Genet 78:279-290

22. Tekendo-Ngongang C, Agenbag G, Bope CD, Esterhuizen Al, Wonkam A (2019) Noonan Syndrome in South Africa: Clinical and Molecular Profiles. Front Genet 10:333

23. El Bouchikhi I, Belhassan K, Moufid FZ, Iraqui Houssaini M, Bouguenouch L, Samri I, Atmani S, Ouldim K (2016) Noonan syndrome-causing genes: Molecular update and an assessment of the mutation rate. Int J Pediatr Adolesc Med 3:133-142

24. Chinton J, Huckstadt V, Moresco A, Gravina LP, Obregon MG (2019) Clinical and molecular characterization of children with Noonan syndrome and other RASopathies in Argentina. Arch Argent Pediatr 117:330-337

25. Bertola DR, Castro MAA, Yamamoto GL, Honjo RS, Ceroni JR, Buscarilli MM, Freitas AB, Malaquias AC, Pereira AC, Jorge AAL, Passos-Bueno MR, Kim CA (2020) Phenotype-genotype analysis of 242 individuals with RASopathies: 18-year experience of a tertiary center in Brazil. Am J Med Genet C Semin Med Genet 184:896-911

26. Yaoita M, Niihori T, Mizuno S, Okamoto N, Hayashi S, Watanabe A, Yokozawa M, et al. (2016) Spectrum of mutations and genotype-phenotype analysis in Noonan syndrome patients with RIT1 mutations. Hum Genet 135:209-222

27. Bertola DR, Yamamoto GL, Almeida TF, Buscarilli M, Jorge AA, Malaquias AC, Kim CA, Takahashi VN, Passos-Bueno MR, Pereira AC (2014) Further evidence of the importance of RIT1 in Noonan syndrome. Am J Med Genet A 164A:2952-2957 
28. Gos M, Fahiminiya S, Poznanski J, Klapecki J, Obersztyn E, Piotrowicz M, Wierzba J, Posmyk R, Bal J, Majewski J (2014) Contribution of RIT1 mutations to the pathogenesis of Noonan syndrome: four new cases and further evidence of heterogeneity. Am J Med Genet A 164A:2310-2316

29. Kouz K, Lissewski C, Spranger S, Mitter D, Riess A, Lopez-Gonzalez V, Luttgen S, et al. (2016) Genotype and phenotype in patients with Noonan syndrome and a RIT1 mutation. Genet Med 18:1226-1234

30. Tartaglia M, Pennacchio LA, Zhao C, Yadav KK, Fodale V, Sarkozy A, Pandit B, Oishi K, Martinelli S, Schackwitz W, Ustaszewska A, Martin J, Bristow J, Carta C, Lepri F, Neri C, Vasta I, Gibson K, Curry CJ, Siguero JP, Digilio MC, Zampino G, Dallapiccola B, Bar-Sagi D, Gelb BD (2007) Gain-of-function SOS1 mutations cause a distinctive form of Noonan syndrome. Nat Genet 39:75-79

31. Roberts AE, Araki T, Swanson KD, Montgomery KT, Schiripo TA, Joshi VA, Li L, Yassin Y, Tamburino AM, Neel BG, Kucherlapati RS (2007) Germline gain-of-function mutations in SOS1 cause Noonan syndrome. Nat Genet 39:70-74

32. Lepri F, De Luca A, Stella L, Rossi C, Baldassarre G, Pantaleoni F, Cordeddu V, et al. (2011) SOS1 mutations in Noonan syndrome: molecular spectrum, structural insights on pathogenic effects, and genotype-phenotype correlations. Hum Mutat $32: 760-772$

33. Schubbert S, Zenker M, Rowe SL, Boll S, Klein C, Bollag G, van der Burgt I, Musante L, Kalscheuer V, Wehner LE, Nguyen H, West B, Zhang KY, Sistermans E, Rauch A, Niemeyer CM, Shannon K, Kratz CP (2006) Germline KRAS mutations cause Noonan syndrome. Nat Genet 38:331-336

34. Mazhab-Jafari MT, Marshall CB, Smith MJ, Gasmi-Seabrook GM, Stathopulos PB, Inagaki F, Kay LE, Neel BG, Ikura M (2015) Oncogenic and RASopathy-associated K-RAS mutations relieve membrane-dependent occlusion of the effectorbinding site. Proc Natl Acad Sci U S A 112:6625-6630

35. Niihori T, Aoki Y, Narumi Y, Neri G, Cave H, Verloes A, Okamoto N, Hennekam RC, Gillessen-Kaesbach G, Wieczorek D, Kavamura MI, Kurosawa K, Ohashi H, Wilson L, Heron D, Bonneau D, Corona G, Kaname T, Naritomi K, Baumann C, Matsumoto N, Kato K, Kure S, Matsubara Y (2006) Germline KRAS and BRAF mutations in cardio-facio-cutaneous syndrome. Nat Genet 38:294-296

36. Carta C, Pantaleoni F, Bocchinfuso G, Stella L, Vasta I, Sarkozy A, Digilio C, Palleschi A, Pizzuti A, Grammatico P, Zampino G, Dallapiccola B, Gelb BD, Tartaglia M (2006) Germline missense mutations affecting KRAS Isoform B are associated with a severe Noonan syndrome phenotype. Am J Hum Genet 79:129-135

37. Razzaque MA, Nishizawa T, Komoike Y, Yagi H, Furutani M, Amo R, Kamisago M, Momma K, Katayama H, Nakagawa M, Fujiwara Y, Matsushima M, Mizuno K, Tokuyama M, Hirota H, Muneuchi J, Higashinakagawa T, Matsuoka R (2007) Germline gain-of-function mutations in RAF1 cause Noonan syndrome. Nat Genet 39:1013-1017

38. Cordeddu V, Di Schiavi E, Pennacchio LA, Ma'ayan A, Sarkozy A, Fodale V, Cecchetti S, et al. (2009) Mutation of SHOC2 promotes aberrant protein N-myristoylation and causes Noonan-like syndrome with loose anagen hair. Nat Genet 41:10221026

39. Baldassarre G, Mussa A, Banaudi E, Rossi C, Tartaglia M, Silengo M, Ferrero GB (2014) Phenotypic variability associated with the invariant SHOC2 c.4A > G (p.Ser2Gly) missense mutation. Am J Med Genet A 164A:3120-3125

40. Martinelli S, De Luca A, Stellacci E, Rossi C, Checquolo S, Lepri F, Caputo V, et al. (2010) Heterozygous germline mutations in the CBL tumor-suppressor gene cause a Noonan syndrome-like phenotype. Am J Hum Genet 87:250-257

41. Niemeyer CM, Kang MW, Shin DH, Furlan I, Erlacher M, Bunin NJ, Bunda S, et al. (2010) Germline CBL mutations cause developmental abnormalities and predispose to juvenile myelomonocytic leukemia. Nat Genet 42:794-800

42. Leung GKC, Luk HM, Tang VHM, Gao WW, Mak CCY, Yu MHC, Wong WL, Chu YWY, Yang WL, Wong WHS, Ma ACH, Leung AYH, Jin DY, Chan KYK, Allanson J, Lo IFM, Chung BHY (2018) Integrating Functional Analysis in the Next-Generation Sequencing Diagnostic Pipeline of RASopathies. Sci Rep 8:2421

43. Gelb BD, Tartaglia M (2011) RAS signaling pathway mutations and hypertrophic cardiomyopathy: getting into and out of the thick of it. J Clin Invest 121:844-847

44. Chen PC, Wakimoto H, Conner D, Araki T, Yuan T, Roberts A, Seidman C, Bronson R, Neel B, Seidman JG, Kucherlapati R (2010) Activation of multiple signaling pathways causes developmental defects in mice with a Noonan syndrome- 
associated Sos1 mutation. J Clin Invest 120:4353-4365

45. Wu X, Simpson J, Hong JH, Kim KH, Thavarajah NK, Backx PH, Neel BG, Araki T (2011) MEK-ERK pathway modulation ameliorates disease phenotypes in a mouse model of Noonan syndrome associated with the Raf1(L613V) mutation. J Clin Invest 121:1009-1025

46. Calcagni G, Adorisio R, Martinelli S, Grutter G, Baban A, Versacci P, Digilio MC, Drago F, Gelb BD, Tartaglia M, Marino B (2018) Clinical Presentation and Natural History of Hypertrophic Cardiomyopathy in RASopathies. Heart Fail Clin 14:225235

47. Dori Y, Smith C, Pinto E, Snyder K, March ME, Hakonarson H, Belasco J (2020) Severe Lymphatic Disorder Resolved With MEK Inhibition in a Patient With Noonan Syndrome and SOS1 Mutation. Pediatrics 146

\section{Supplementary Files}

This is a list of supplementary files associated with this preprint. Click to download.

- Tables1.docx 